\title{
Large Homing Flight Distances Flown by Female Sphex pensylvanicus Linnaeus, 1763 (Hymenoptera: Sphecidae: Sphecinae) in Sioux City, Iowa, USA ${ }^{1}$
}

\author{
G. K. Lechner ${ }^{2}$
}

Abstract: Marked female Sphex pensylvanicus were recaptured at their nest some 1.3 $9.7 \mathrm{~km}$ away from the release sites.

Key Words: Homing flight distances, Sphex pensylvanicus, Hymenoptera: Sphecidae: Sphecinae, Iowa, USA

The Great Black Wasp, Sphex pensylvanicus Linnaeus, 1763, is a large (20$35 \mathrm{~mm}$ long, Figure 1) solitary fossorial wasp found transcontinentally in most of the United States (Bohart and Menke 1976) and into Ontario, Canada (Buck 2004). From a review of the Catalog of Sphecidae (Pulawski 2014), it does not appear that any large-scale study has included the flight distance of $S$. pensylvanicus although two papers on the behavior of this wasp reported that both males and females routinely flew 55-60 meters between the nests and hunting, feeding, and sleeping locations (Kurczewski 1997, 1998). Herein, I report flight distances of $S$. pensylvanicus, as part of my long-term studies of this sphecid.

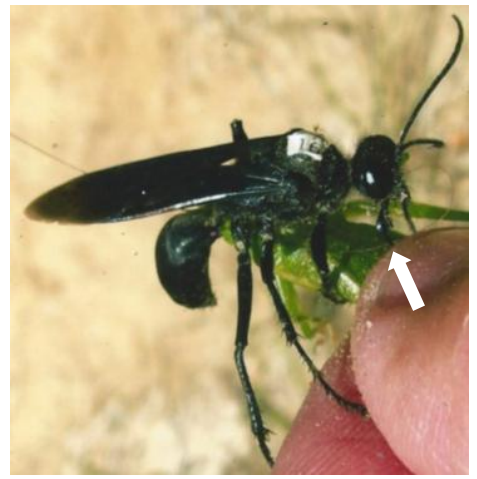

Figure 1. Female Sphex pensylvanicus holding a katydid (Orthoptera: Tettigoniidae). Note the hyperextended mandibles (arrow points to right mandible) and the tag system (wasp \# 16) generally used to identify individual wasps in this long-term study. Photograph taken by the author on July 20, 2012.

Every summer since 2003, I have been observing the activities of an aggregation of $S$. pensylvanicus that has been nesting in the soil behind a vertical

\footnotetext{
${ }^{1}$ Submitted on April 13, 2015. Accepted on May 15, 2015. Last revisions received in May 27, 2015.

${ }^{2} 3624$ Virginia Street, Sioux City, Iowa 51104 USA. E-mail: lechnerg_wcqma@yahoo.com
}

DOI: 10.9784/LEB3(2)Lechner.01

Electronically available on July 25, 2015. Mailed on July 27, 2015. 
concrete block retaining wall on a residential lot in Sioux City, Iowa. Wasps captured at this nest site were given a unique identifier by adhering a numbered tag to the scutum using cyanoacrylate glue or by painting a dab of colored paint on the scutum.

From July 2011 to August 2014, I captured and tagged adult $S$. pensylvanicus, transported them by car to distant locations, and immediately released them. During these trips the wasps were placed in clear plastic jars and had full visual access to their environment. Travel times to the release sites varied, but the longest trip did not exceed circa 20 minutes. Angular directions and flight distances back to the nest (Table 1) were calculated on the assumption that the wasps flew in a straight line and were derived using the website www.daft.logic.com/projects-google-maps-distance.

\section{Results and Discussion}

Table 1 summarizes directions and distances flown by the wasps from the nest to the release site. Several wasps were able to home or return to the nest multiple times over urban and rural terrains.

The Homing Instinct (Heinrich 2014) has almost 250 citations including mammals, birds, reptiles, fish, and insects reflecting how widespread the tendency of returning home is in the animal world. Much has been published on insect flight distances, and it is no surprise that an insect of the economic importance as the European Honey Bee, Apis mellifera Linnaeus, 1758 (Apidae) has long been a subject of flight range research (Eckert 1933, Ribbands 1951, Pahl et al. 2011). These authors report that A. mellifera can fly, at least, 7 miles (approximately $11.2 \mathrm{~km}$ ) back to their nests. Goulson and Stout (2001) completed a large-scale study of over 400 bumblebees (Apidae), Bombus terrestris (Linnaeus, 1758), reporting homing distances of up to $9.8 \mathrm{~km}$.

Regarding wasps (Hymenoptera), the 19th century French entomologist Jean-Henri Fabre (1823-1915) demonstrated that Cerceris tuberculata (Villers, 1787) (Crabronidae) could return to their nests when transported several kilometers away (cited in Goulson and Stout 2001). More recently, Nalepa et al. (2013) suggested that individual hunting flights of Cerceris fumipennis Say, 1837 are less than 200 meters. Many individuals of the digger wasp, Argogorytes carbonarius (Smith, 1856) (Crabronidae), in New Zealand were given homing challenges of 500 meters and were found capable of making the return (Schöne et al. 1993). Brief remarks on flight distances of wasps in the United States were reported by Rau (1931) for the sphecid wasps, Sceliphron caementarium (Drury, 1773), Trypoxylon clavatum Say, 1837 (Crabronidae, misprinted Trypoxylon olvatum in Rau 1931), T. lactitarse de Saussure, 1867 (Trypoxylon albopilosum, in Rau 1931, is a junior synonym), and Isodontia auripes (Fernald, 1906) (Sphecidae, Chlorion auripes in Rau 1931). These flight tests involved between $1-4$ individuals of any one species. The wasps were transported and released at sites no more than 2 miles $(3.2 \mathrm{~km})$ from their nests. 
The Great Golden Digger Wasp, Sphex ichneumoneus (Linnaeus, 1758), was the subject of a study by Ristich (1953). In his report, he stated that two of these sphecid wasps were caught 1.5 miles (approximately $2.4 \mathrm{~km}$ ) from their nesting colony.

Table 1. Homing flight distances of female Sphex pensylvanicus Linnaeus, 1763 in Sioux City, Iowa, USA (July 2011 to August 2014). Wasps that were not recaptured are denoted by ---.

\begin{tabular}{|c|c|c|c|c|}
\hline $\begin{array}{c}\text { Wasp } \\
\text { Identification }\end{array}$ & $\begin{array}{l}\text { Capture and } \\
\text { release date }\end{array}$ & $\begin{array}{l}\text { Minimum } \\
\text { distance } \\
\text { flown, in } \\
\text { miles }(\mathbf{k m})\end{array}$ & $\begin{array}{l}\text { Direction } \\
\text { from the } \\
\text { nest to the } \\
\text { release point } \\
\text { (in degrees } \\
\text { from due } \\
\text { north) }\end{array}$ & $\begin{array}{l}\text { Recapture } \\
\text { Date }\end{array}$ \\
\hline \multirow{6}{*}{ Yellow } & July 17,2011 & $0.85(1.3)$ & 180 & July 19,2011 \\
\hline & July 19,2011 & $1.3(2.1)$ & 189 & July 20, 2011 \\
\hline & July 20, 2011 & $1.56(2.6)$ & 346 & July 20, 2011 \\
\hline & July 21,2011 & $1.9(3)$ & 73 & July 21,2011 \\
\hline & July 22, 2011 & $2.5(4)$ & 300 & July 22,2011 \\
\hline & July 23, 2011 & $3.1(4.9)$ & 180 & --- \\
\hline \multirow{3}{*}{ White } & July 31,2011 & $2.8(4.5)$ & 6 & August 6, 2011 \\
\hline & August 7, 2011 & $3.4(5.44)$ & 7 & August 11, 2011 \\
\hline & August 17,2011 & $3.4(5.44)$ & 7 & --- \\
\hline \multirow{3}{*}{ Silver } & July 28,2011 & $2.5(4)$ & 0 & July 29, 2011 \\
\hline & July 29,2011 & $3.6(5.76)$ & 105 & July 31,2011 \\
\hline & August 2, 2011 & $4(6.4)$ & 12 & --- \\
\hline Blue & August 12, 2011 & $4.8(6.7)$ & 12 & --- \\
\hline Brown & August 13,2011 & $4.1(6.7)$ & 197 & --- \\
\hline$\# 1$ & June 25,2012 & $0.85(1.3)$ & 180 & --- \\
\hline \multirow{5}{*}{$\# 7$} & July 6, 2012 & $0.85(1.3)$ & 180 & July 7, 2012 \\
\hline & July 7, 2012 & $1.56(2.6)$ & 346 & July 8, 2012 \\
\hline & July 8, 2012 & $1.9(3)$ & 73 & July 8,2012 \\
\hline & July 9, 2012 & $3.59(5.74)$ & 8 & July 10, 2012 \\
\hline & July 11,2012 & $4.6(7.32)$ & 12 & July 12,2012 \\
\hline \multirow{2}{*}{$\# 14$} & July 11,2012 & $4.6(7.32)$ & 12 & July 12,2012 \\
\hline & July 14,2012 & $6.14(9.7)$ & 13 & July 15,2012 \\
\hline \# 17 & July 14,2012 & $6.14(9.7)$ & 13 & --- \\
\hline$\# 27$ & July 27,2012 & $7.14(11.4)$ & 12 & --- \\
\hline \multirow{2}{*}{$\# 14^{1}$} & July 31,2013 & $0.85(1.3)$ & 180 & August 1, 2013 \\
\hline & August 1, 2013 & $3.4(5.44)$ & 7 & --- \\
\hline$\# 4$ & August 3, 2014 & $0.85(1.3)$ & 180 & --- \\
\hline \#3 & August 21, 2014 & $7.14(11.4)$ & 12 & --- \\
\hline
\end{tabular}

${ }^{1}$ Wasp \# 14 of 2012 is different from wasp \# 14 of 2013.

Although the number of female $S$. pensylvanicus wasps herein reported is too small to derive any statistically valid conclusions about the maximum or 
average flight distances, the multiple returns by some wasps and the rather impressive distances are noteworthy. Of particular interest are the, at least, 17.02 $\mathrm{km}$ (total) wasp \# 14 flew in two different occasions, flying $9.7 \mathrm{~km}$ on July 14$15,2012$.

\section{Acknowledgements}

I extend my thanks to three reviewers who provided feedback on this paper.

\section{Literature Cited}

Bohart, R. M. and A. S. Menke. 1976. Sphecid Wasps of the World: A Generic Revision. University of California Press. Berkeley, California, USA. 695 pp.

Buck, M. 2004. An annotated checklist of the spheciform wasps of Ontario (Hymenoptera: Ampulicidae, Sphecidae and Crabronidae). Journal of the Entomological Society of Ontario 134:19-83.

Eckert, J. E. 1933. The flight range of the honeybee. Journal of Agricultural Research 47:257285.

Goulson, D. and J. C. Stout. 2001. Homing ability of the Bumble Bee Bombus terrestris (Hymenoptera: Apidae). Apidologie 32(1):105-111. http://dx.doi.org/10.1051/apido:2001115

Heinrich, B. 2014. The Homing Instinct: Meaning and Mystery in Animal Migration. Houghton Mifflin Harcourt. Boston, Massuchussetts and New York, NY, USA. 352 pp.

Kurczewski, F. E. 1997. Activity patterns in a nesting aggregation of Sphex pensylvanicus L. (Hymenoptera: Sphecidae). Journal of Hymenoptera Research 6(2):231-242.

Kurczewski, F. E. 1998. Territoriality and mating behaviour of Sphex pensylvanicus L. (Hymenoptera: Sphecidae). Journal of Hymenoptera Research 7(1):74-83.

Nalepa, C. A., W. H. Swink, P. Merten, and J. E. Moan. 2013. Conservative estimates of hunting distance in Cerceris fumipennis Say (Hymenoptera: Crabronidae). Journal of Entomological Science 48(4): 299-305.

Pahl, M., H. Zhu, J. Tautz, and S. Zhang. 2011. Large scale homing in honeybees. PLoS ONE 6(5):e19669. doi:10.1371/journal.pone.DO19669. 7 pp.

Pulawski, W. J. 2014. Catalog of Sphecidae sensu lato. California Academy of Sciences. Golden Gate Park, San Francisco, California, USA. Available from: http://www.calacademy.org/scientists/projects/catalog-of-sphecidae (Accessed on May 26, 2015.)

Rau, P. 1931. Notes on the homing of several species of wasps (Hym: Chrysididae, Sphegoidea, Vespoidea). Entomological News 42:199-200.

Ribbands, C. R. 1951. The flight range of the Honey Bee. Journal of Animal Ecology 20(2):220226. http://dx.doi.org/10.2307/1541

Ristich, S. S. 1953. A study of the prey, enemies, and habits of the Great-Golden Digger Wasp, Chlorion ichneumoneum (L.). The Canadian Entomologist 85:374-386. http://dx.doi.org/10.4039/Ent85374-10

Schöne, H., A. C. Harris, H. Schöne, and P. A. Mahalski. 1993. Homing after displacement in open and closed containers by the digger wasp Argogorytes carbonarius (Hymenoptera, Sphecidae). Ethology 95:152-156. http://dx.doi.org/10.1111/j.1439-0310.1993.tb00465.x 